\title{
PROTOTYPE AUTOMATIC HIGHT WATER SURFACE DETECTION PADA BAK PENAMPUNGAN AIR PDAM MENGGUNAKAN ULTRASONIC SENSOR BERBASIS MIKROKONTROLER
}

\author{
Imam Bukhari ${ }^{1}$, Dani Fitria Brilianti ${ }^{2}$, Mella Katrina Sari ${ }^{3}$ \\ Email: bukhari.imam@yahoo.co.id \\ DIII Teknik Komputer Politeknik Harapan Bersama \\ Jln. Mataram No. 9 Tegal \\ Telp/Fax (0283) 352000
}

\begin{abstract}
Abstrak
Kemajuan ilmu pengetahuan dan teknologi berperan mewujudkan kehidupan yang lebih baik. Teknologi elektronika merupakan salah satu teknologi yang telah melekat di dalam kehidupan manusia, berbagai alat elektronika praktis dan fleksibel telah banyak diciptakan sehingga membantu memudahkan manusia dalam memenuhi kebutuhannya. Berbagai macam peralatan dengan sistem pengoperasian secara manual semakin ditinggalkan beralih pada peralatan yang serba otomatis, sehingga peralatan otomatis lebih mendominasi dalam kehidupan manusia. Prototype Automatic Hight Water Surface Detection Pada Bak Penampungan Air PDAM Mengunakan Ultrasonic Sensor Berbasis Mikrokontroller Arduino Uno R3 didesain dengan operasional yang sederhana dan mudah pengoperasiannya sehingga mampu bekerja mengendalikan secara otomatis mesin pompa air. Alat ini berfungsi untuk menghidupkan atau mematikan mesin pompa air, jika air pada bak penampung kosong, maka alat ini akan menghidupkan mesin pompa air dan jika air pada bak penampung penuh, maka alat ini akan mematikan mesin pompa air. Alat ini juga dapat mengisi bak air penampungan berdasarkan volume dan tinggi air berdasarkan keperluan dengan cara melakukan inputan nilai dari keypad, hasil akan ditampilkan di LCD (Liquid Crystal Display). Sensor ultasonik berfungsi sebagai alat utama untuk mengetahui ketinggian air pada bak penampungan disertakan dengan rangkaian relay sebagai saklar otomatis untuk mesin pompa air.
\end{abstract}

Kata Kunci: alat kendali, ketinggian air, sensor ultrasonik, mikrokontroler

\section{Pendahuluan}

Seiring dengan percepatan teknologi membuat banyak orang menjadi termotivasi untuk membuat suatu hal yang baru, sesuatu yang dikendalikan secara otomatis menggunakan suatu sistem yang mudah dioperasikan. Dengan alat-alat yang dapat menghemat listrik ataupun sumber daya lainnya seperti penghematan air bila dipadukan dengan sedikit rangkaian elektronika. Pada kenyataannya hal ini juga dapat mengurangi beban pemerintah dalam hal penghematan listrik.

Aliran air PDAM (Perusahaan Daerah Air Minum) khususnya di Kota Tegal sering tidak stabil. Besarnya debit air yang mengalir keluar sangat sedikit antara pagi sampai sore, tapi sangat deras pada malam hari. Hal ini tentu menyulitkan bagi individu atau keluarga yang memiliki banyak aktifitas tetapi tidak memiliki waktu untuk melakukan monitoring persediaan air pada bak penampungan. Pengisian air pada bak penampungan air dengan menggunakan mesin pompa air dimana pompa air berfungsi untuk menghisap air untuk dimasukan ke dalam bak penampungan air atau tedmond. Tedmond biasanya dipakai oleh pengelola air bersih, penampungan air yang besar, kebutuhan rumah tangga sehari-hari, khususnya yang menggunakan mesin pompa air dari dalam sumur dan Perusahaan Daerah Air Minum (PDAM). Semakin meningkatnya kebutuhan air bersih yang berasal dari pegunungan bagi masyarakat Kota Tegal menjadi pertimbangan kita untuk mengurangi pemborosan air yang berakibat akan semakin berkurangnya sumber daya alam. Penggunaan air pegunungan untuk kebutuhan sehari-hari lebih banyak dibandingkan dengan penggunaan air sumur warga. Hal ini disebabkan oleh semakin pesatnya perkembangan dalam bidang perindustrian sehingga berakibat pada tercemarnya lingkungan sekitar pabrik terutama sumber daya air. Oleh karena itu, pemanfaatan air pegunungan yang dialirkan ke rumah-rumah warga tentunya menjadi hal yang vital bagi masyarakat. Fenomena inilah 
yang membuat penulis tergerak untuk melakukan inovasi guna mengurangi resiko terbuangnya air bersih dari bak penampungan air.

Sistem kerja pengisian air ini masih menbutuhkan pengawasan penuh. Pompa air harus dihidupkan bila bak penampungan air kosong dan juga sebaliknya pompa harus dimatikan bila bak penampungan air sudah penuh. Hal ini cukup merepotkan karena bila lupa mematikan pompa air, maka air yang ada di dalam bak penampungan terlalu penuh hingga meluap dan ini akan mendapatkan kerugian.

Pengelolaan air pada bak penampungan air sudah dikembangkan sebelumnya dengan sistem kontrol berupa katup dan pelampung. Sistem kerjanya sederhana, keran air manual yang biasanya untuk menutup dan membuka kembali aliran air dengan cara diputar, sedangkan keran katup dan pelampung menutup dan membuka bekerja secara otomatis. Katup berfungsi untuk menutup dan membuka aliran air ke dalam bak penampungan yang dikontrol oleh pelampung bahwa pelampung dikontrol oleh tinggkat ketinggian dan kerendahan air. Pelampung berfungsi untuk memberi batasan kapan katup akan membuka dan menutup aliran air pada posisi tertentu sesuai dengan panjang besi pelampung. Biasanya panjangnya berkisar 10 cm sampai dengan $30 \mathrm{~cm}$.

Prinsip kerja kedua alat ini sama yaitu tombol (pemutus dan penghubung arus listrik). Bedanya gaya untuk membuka tuas penghubung arusnya adalah gaya berat pelampung untuk level control, sedang untuk pressure switch adalah gaya akibat tekanan air di sisi keluaran pompa, namun akibatnya terhadap operasi pompa berbeda. Bila menggunakan level control, pompa akan mati bila kedua pelampung mengambang di permukaan level air dan hidup lagi manakala kedua pelampung tergantung, artinya muka air berada di bawah kedua pelampung yang tergantung pada switch. Jadi hidup matinya pompa (start-stop) cukup lama. Sedangkan pressure switch mengakibatkan start-stop lebih sering karena begitu tekanan sisi keluar pompa turun akibat keran terbuka, maka pompa akan start dan akan stop sesaat setelah semua aliran keluar pompa tertutup. Konsekuensinya umur pressure switch biasanya lebih pendek (lebih cepat rusak).

Telah dipaparkan pada beberapa jurnal atau literatur yang berkaitan dengan alat deteksi/kendali ketinggian permukaan air pada bak penampungan air bersih. Salah satunya adalah penelitian yang dilakukan oleh Sumardi ${ }^{1}$ pada tahun 2016 yang berjudul "Sistem Kontrol Pengisian Air Otomatis Dengan Dua Sumber Suplai Berbasis Mikrokontroler (ATmega 8535)". Hasil percobaan menunjukkan sensor air berhasil memberikan logika Low atau High pada keluarannya sebagai fungsinya untuk memberikan sinyal masukan pada port mikrokontrol. Pada kondisi high, sensor air mampu memberikan nilai tegangan 4,89 Volt DC untuk digunakan sebagai masukan mikrokontroler. Pada kondisi low, sensor air mampu memberikan nilai tegangan 0,11 Volt DC sebagai masukan mikrokontroler ketika elektroda tehubung dengan common oleh media air. Driver masukan terbukti dapat digunakan untuk menggendalikan kerja dari motor pompa 220 Volt AC dan lampu indikator 12 Volt DC.

Penelitian selanjutnya dilakukan oleh Eko Syamsuddin ${ }^{2}$ tahun 2011 yang berjudul "Perancangan Alat Pengatur Suhu Air dan Pengisian Bak Air Secara Otomatis Melalui Short Message Service Berbasis Mikrokontroler". Pada rancangan alat pengatur suhu ini digunakan sensor suhu IC LM35D yang dapat mengeluarkan tegangan yang linear sebanding dengan kenaikan temperatur, sehingga suhu air bisa diatur sesuai yang diinginkan. Dari hasil pengujian dapat dilihat bahwa sistem pengatur suhu ini dapat menstabilkan suhu air pada nilai yang dikirimkan melalui SMS, dimana saat suhu bak penampungan turun heater akan memanaskan air hingga suhu naik pada titik stabil dan dimana saat suhu naik, heater akan off sehingga suhu akan turun sampai dengan titik stabil. Selain itu, pengujian alat ini menyatakan bahwa rancangan sistem dapat mengaktifkan pompa air ketika batas air 
berada dibawah batas bawah dan mengisi kembali hingga batas atas.

Penelitian lain yang berjudul "Rancang Bangun Sistem Monitoring Volume dan Pengisian Air Menggunakan Sensor Ultrasonic Berbasis Mikrokontroler AVR Atmega 8" dilakukan oleh Adhitya Permana ${ }^{3}$ tahun 2015. Pengujian sistem dilakukan pada bak penampungan air dengan ukuran $65 \times 45 \times 38 \mathrm{~cm}$. Hasil pengujian menunjukkan, sistem monitoring ini dapat menampilkan ketinggian air secara aktual dan melakukan pengisian air secara otomatis pada saat bak penampungan air kosong dan menghentikan proses pengisian saat air mencapai ketinggian yang telah diatur pengguna yaitu $20 \mathrm{~cm}$, sehingga memudahkan dalam mengontrol persediaan air.

Penelitian serupa dilakukan oleh Imam Mukhlisin ${ }^{4}$ pada tahun 2017 yang berjudul "Pendeteksi Volume Tandon Air Secara Otomatis Menggunakan Sensor Ultrasonic Berbasis Arduino Uno R3". Sistem pendeteksi volume tandon air ini menggunakan sensor ultrasonic SRF HRC04. Mikrokontroler Arduino Uno R3 digunakan sebagai sistem control sinyal masukan dan keluaran serta LCD 16x2 sebagai penampilan datanya. Pengujian dilakukan dengan memberikan variasi jarak sensor terhadap muka air dari $2 \mathrm{~cm}$ sampai $18 \mathrm{~cm}$. Sistem yang telah dibuat dilakukan kalibrasi agar layak digunakan sebagai alat ukur ketinggian air. Berdasarkan hasil penelitian dapat disimpulkan bahwa sistem pendeteksi volume tandon air dapat bekerja dengan baik sesuai dengan yang diharapkan yaitu dapat mengontrol volume ketinggian air pada tandon penampungan secara otomatis dengan ketepatan 99,10\% dan kesalahan 0,90\%.

Dari berbagai macam sistem kerja alat pada penelitian sebelumnya, maka selanjutnya dalam penelitian ini, peneliti akan membuat sebuah pengembangan dengan memasang sensor ultrasonik untuk mendeteksi ketinggian permukaan air pada bak penampungan air PDAM Kota Tegal berbasis mikrokontroler Arduino Uno R3. Alat ini berfungsi untuk menghidupkan atau mematikan mesin pompa air, jika air pada bak penampung kosong, maka alat ini akan menghidupkan mesin pompa air dan jika air pada bak penampung penuh, maka alat ini akan mematikan mesin pompa air. Alat ini juga dapat mengisi bak air penampungan berdasarkan volume dan tinggi air berdasarkan keperluan dengan cara melakukan inputan nilai dari keypad, hasil akan ditampilkan di LCD (Liquid Crystal Display). Sensor ultrasonik berfungsi sebagai alat utama untuk mengetahui ketinggian air pada bak penampungan disertakan dengan rangkaian relay sebagai saklar otomatis untuk mesin pompa air.

Melihat dari latar belakang tersebut, maka penulis akan membuat penelitian dengan judul, "Rancang Bangun Automatic Hight Water Level Detection Pada Bak Penampungan Air PDAM Mengunakan Ultrasonic Sensor Berbasis Mikrokontroler". Alat pendeteksi tinggi permukaan air secara otomatis dengan mengunakan sensor ultrasonik yang berfungsi membaca ketinggian air pada bak penampungan serta dapat mematikan pompa air bila kondisi air pada bak penampungan sudah terisi penuh dan menghidupkan kembali pompa air bila air dalam bak penampungan dalam keadaan kosong secara otomatis.

\section{Metode Penelitian}

\subsection{Tempat dan Waktu Penelitian}

Pembuatan desain automatic high water level detection ini akan dilakukan di laboratorium hardware program studi D3 Teknik Komputer Politeknik Harapan Bersama dan akan diterapkan pada rumahrumah yang menggunakan sistem penyediaan air bersih yang bersumber dari PDAM Kota Tegal. Waktu yang dibutuhkan untuk melakukan penelitian ini hingga publikasi jurnal yaitu kurang lebih 1 tahun.

\subsection{Jenis Penelitian}

Jenis penelitian ini adalah rancang bangun automatic hight water surface detection pada bak penampungan air PDAM menggunakan ultrasonic sensor berbasis mikrokontroler yang didesain dengan operasional sederhana dan mudah pengoperasiannya sehingga mampu bekerja 
mengendalikan secara otomatis mesin pompa air. Alat ini berfungsi untuk menghidupkan atau mematikan mesin pompa air, jika air pada bak penampung kosong, maka alat ini akan menghidupkan mesin pompa air dan jika air pada bak penampung penuh, maka alat ini akan mematikan mesin pompa air. Alat ini juga dapat mengisi bak air penampungan berdasarkan volume dan tinggi air berdasarkan keperluan dengan cara melakukan inputan nilai dari keypad, hasil akan ditampilkan di LCD (Liquid Crystal Display).

\subsection{Alat dan Bahan}

Alat dan bahan yang digunakan dalam pembuatan alat ini antara lain sebagai berikut:

a. Perangkat Keras

1) Processor Pentium (R) dual- core $\mathrm{Cpu}$ T4500@2.30GHz (2CPUs), 2.3 GHz

2) Memory $1024 \mathrm{MB}$ RAM

3) Monitor Generic PnP monitor 1366 X 768; 32 bit $60 \mathrm{~Hz}$

4) Arduino Uno R3

5) Sensor Ultrasonik SRF05

6) Keypad 4x4

7) LCD (Liquid Crystal Display) 16x2 character

8) Power Supply

b. Perangkat Lunak

1) Sistem Operasi Windows 7 Ultimate 32-bit

2) IDE Arduino

\subsection{Prosedur Penelitian}

\section{a. Sistem Pengukuran}

Prinsip kerja dari sistem deteksi ketinggian permukaan air otomatis ini dimana semua instruksi untuk menjalankan alat ini terdapat pada mikrokontroler Arduino Uno R3 sebagai pengontrol utama. Mikrokontroler Arduino merupakan kit elektronik atau papan rangkaian elektronik open source yang di dalamnya terdapat komponen utama yaitu sebuah chip mikrokontroler dengan jenis AVR dari perusahaan Atmel (Efendi Ilham dalam Mauludin, 2016).

Arduino berfungsi sebagai pengendali mikro single-board yang bersifat open-source, diturunkan dari Wiring platform, serta dirancang untuk memudahkan penggunaan media atau alat elektronik dalam berbagai bidang. Hardware pada mikrokontroler ini memiliki prosesor Atmel AVR serta software yang memiliki bahasa pemrogramanya sendiri (Putri Mandarani dan Reza Ariani, 2016) ${ }^{6}$. Dapat disimpulkan bahwa
Arduino merupakan sebuah perangkat kompleks yang dapat diprogram untuk melakukan banyak hal dan kegiatan baik untuk kegiatan yang sifatnya simple (ringan) hingga berbagai proyek elektronik yang bersifat kompleks (berat).

Alat ini akan bekerja sesaat setelah sistem dihidupkan kemudian akan tampil pada LCD berupa perintah untuk menginputkan volume dan ketinggian air, selanjutnya volume dan ketinggian air dapat di inputkan dengan menekan tombol keypad, setelah itu transmitter akan mengirimkan seberkas gelombang ultrasonik, lalu diukur waktu yang dibutuhkan hingga datangnya pantulan dari objek. Lamanya waktu ini sebanding dengan dua kali jarak sensor dengan objek, sehingga jarak sensor dengan objek dapat ditentukan dengan persamaan:

Jarak $=($ kecepatan_suara $\times$ waktu_pantulan $) / 2$

Kecepatan suara pada media udara dipengaruhi oleh temperatur dan juga kelembaban. Untuk media udara pada temperature $20^{\circ} \mathrm{C}$ kecepatan suara adalah $344 \mathrm{~m} / \mathrm{s}$. Artinya untuk menempuh jarak 344 m dibutuhkan waktu 1 detik. Atau untuk menempuh jarak $1 \mathrm{~m}$ butuh waktu $1 / 344 \mathrm{~s}$ atau $0,0029 \mathrm{~s}$. Jika menempuh jarak $1 \mathrm{~cm}(1 \mathrm{~cm}=0,01 \mathrm{~m})$, maka butuh waktu $0,01 \mathrm{x}$ $0,0029 \mathrm{~s}=0,000029 \mathrm{~s}(29 \mu \mathrm{s})$. Jadi, kesimpulannya untuk menempuh jarak $1 \mathrm{~cm}$ dibutuhkan waktu $58 \mu \mathrm{s}$. Dengan kata lain, untuk menghitung jarak tempuh = waktu tempuh/58 (dalam satuan $\mathrm{cm})$.

Setelah data yang diinputkan diproses oleh mikrokontroler Arduino Uno R3, maka sensor ultrasonik akan diaktifkan. Hal ini berarti pompa air mulai hidup dan melakukan pengisian air pada bak penampungan air. Selama proses pengisian air ini, sensor ultrasonik akan terus memonitoring ketinggian permukaan air dengan cara membandingkan volume dan ketinggian air pada bak penampungan air dengan standar/batasan yang telah ditentukan sebelumnya. Apabila volume dan ketinggian air sudah mencapai batasan tertentu, maka pompa air secara otomatis akan mati dan berhenti melakukan pengisian air. Begitu juga sebaliknya, jika volume dan ketinggian air belum mencapai batasan yang telah ditentukan, maka pompa air akan terus hidup dan melakukan pengisian air.

\section{b. Prosedur Pengujian}

1) Pengujian Rangkaian Power Supply

Rangkaian power supply merupakan sumber tegangan dan arus dari semua rangkaian yang digunakan pada alat. Pada alat 
yang penulis buat ini rangkaian catu daya mengeluarkan tegangan output sebesar $12 \mathrm{~V}$ DC dan 5V DC. Tegangan 12V DC ditujukan untuk arduino yang dihubungkan dengan jack connector dan sebagai tegangan supply untuk amplifier sebagai penguat output ISD, sedangkan tegangan 5V DC digunakan sebagai tegangan input dari sensor PIR, sensor SRF05 dan LCD. Berikut ini adalah langkah-langkah yang akan dilakukan pada proses pengujian rangkaian power supply:

a) Mengaktifkan transformator.

b) Menentukan tegangan keluaran $12 \mathrm{~V}$ DC dan tegangan 5V DC pada rangkaian power supply.

c) Ukur tegangan keluaran dari power supply dengan menggunakan alat ukur multimeter.

d) Amati dan catat data yang terukur pada rangkaian tersebut.

2) Pengujian Rangkaian Arduino Uno R3

Pengujian selanjutnya dilakukan pada mikrokontroler Arduino Uno R3 yang mana bagian ini merupakan pusat pengolahan data pada sistem peringatan otomatis ini. Pengujian yang akan dilakukan ini merupakan pengujian dengan memprogram mikrokontroler arduino dan mengukur pin output menggunakan multimeter.

Langkah-langkah untuk pengujian Arduino Uno R3:

a) Membuat program menggunakan software pada arduino Uno R3, beri logika 1 (HIGH) pada PIN 1 dan pada PIN 2 beri logika 0 (LOW) seperti program di bawah ini:

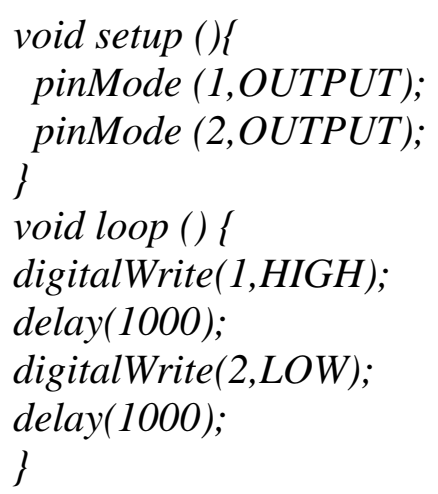

Setelah program selesai dibuat, maka download program tersebut ke dalam mikrokontroler arduino Uno R3 menggunakan kabel downloader. b) Mengkalibrasi multi meter dan letakan selector pada V DC dengan batas skala 10V DC.

c) Memberikan suplai 5V DC pada mikrokontroler melakukan pengukuran pada PIN 1 dan PIN 2 arduino

3) Pengujian Rangkaian Sensor Utrasonik SRF05

Pada pengujian ini yaitu menghitung pembacaan data jarak sensor terhadap benda atau objek yang berada di depan sensor. Tampilan nilai jarak dari pembacaan sensor dilihat dari serial monitor pada aplikasi arduino saat rangkaian mikrokontroller terkoneksi dengan PC.

Untuk melakukan pengukuran sensor SRF05 dapat dilakukan langkah - langkah pengujian sebagai berikut:

a) Berikan tegangan supply pada Vcc dan Gnd sebesar 5V DC

b) Hubungkan pin trigger dan echo pada pin arduino

c) Upload program yang telah di-compile

d) Posisikan mistar di depan sensor SRF05

e) Posisikan sebuah objek yang dapat memantulkan gelombang ultrasonik di depan sensor SRF05

f) Sesuaikan jarak objek dengan mistar

g) Amati jarak objek sebenarnya dengan yang terbaca oleh sensor

h) Ukurlah tegangan pada pin trigger dan echo menggunakan multimeter digital

Dalam melakukan pengukuran jarak yang terbaca oleh sensor dengan jarak yang sebenarnya terdapat kesalahan, dan untuk menentukan persentase kesalahan tersebut dapatlah digunakan rumus sebagai berikut:

((Jarak Pembacaan Sensor - Jarak

Sebenarnya) x 100) / Jarak Pembacaan

\section{Sensor}

4) Pengujian Rangkaian LCD

Untuk pengujian LCD dilakukan dengan memasukkan program ke Arduino dengan melakukan beberapa langkah sebagai berikut:

a) Memasang kabel input dari LCD ke pin arduino

b) Membuat program menggunakan software pada arduino Uno R3. 
Void loop \{

Lcd.setCursor $(0,0)$;

Lcd.Println("T.A Insyaallah"); \}

\section{Hasil dan Pembahasan}

\subsection{Pengujian Power Supply}

Tabel 3.1. Hasil Pengukuran Power Supply

\begin{tabular}{|c|c|c|}
\hline No. & Titik Pengukuran & $\begin{array}{c}\text { Tegangan } \\
\text { Terukur }\end{array}$ \\
\hline 1 & TP1 & 12.2 V AC \\
\hline 2 & TP2 & 15.5 V DC \\
\hline 3 & TP3 & 11.8 V DC \\
\hline 4 & TP4 & 4.9 V DC \\
\hline
\end{tabular}

Power supply mengeluarkan tegangan $4.9 \mathrm{~V}$ DC dan 11.8 VDC. Yang mana tegangan 4.9 VDC dan $11.8 \mathrm{~V}$ DC ini diperoleh dari tegangan $12 \mathrm{~V}$ AC yang disearahkan oleh dioda bridge dan menghasilkan tegangan output sebesar 15.5 VDC yang kemudian tegangannya akan diregulasi menggunakan IC regulator 7812 sehingga keluaran dari IC regulator ini menjadi 11.8 V DC kemudian tegangan ini akan diregulasi lagi menggunakan IC regulator 7805 yang meregulasi tegangan menjadi $4.9 \mathrm{~V} \mathrm{DC}$.

Hal yang perlu diperhatikan dalam penggunaan IC regulator ini yaitu penggunaan arus yang sesuai dengan kapasitas yang dapat ditampung oleh IC regulator tersebut. Jika kelebihan arus, maka IC regulator cepat panas dan bisa mngakibatkan komponen tersebut rusak.

Tegangan 11.8 V DC ini akan digunakan sebagai tegangan input pada amplifier dan sebagai tegangan input untuk arduino pada jack connector dan tegangan $4.9 \mathrm{~V}$ DC digunakan sebagai tegangan input dari sensor PIR, dan modul ISD1820.

\subsection{Rangkaian Arduino Uno R3}

Tabel 3.2. Hasil Pengujian Rangkaian Arduino Uno R3

\begin{tabular}{|c|c|}
\hline Waktu (detik) & $\begin{array}{c}\text { Keluaran Avometer } \\
\text { (PIN 4) }\end{array}$ \\
\hline 1 & 1 \\
\hline 2 & 0 \\
\hline 3 & 1 \\
\hline 4 & 0 \\
\hline 5 & 1 \\
\hline 6 & 0 \\
\hline 7 & 1 \\
\hline 8 & 0 \\
\hline
\end{tabular}

Berdasarkan pada tabel 3.2 arduino yang digunakan pada sistem ini berfungsi dengan baik. Hal ini dikarenakan pin 4 pada arduino dapat bernilai 1 dan 0 .

\subsection{Rangkaian Sensor Ultrasonic SRF05}

Tabel 3.3. Hasil Pembacaan Data Sensor Ultrasonik SRF05

\begin{tabular}{cccc}
\hline No. & $\begin{array}{c}\text { Jarak } \\
\text { Sebenamya } \\
(\mathbf{c m})\end{array}$ & $\begin{array}{c}\text { Jarak } \\
\text { Sensor } \\
(\mathbf{c m})\end{array}$ & $\begin{array}{c}\text { Enror } \\
(\mathbf{\%})\end{array}$ \\
\hline 1. & 10 & 10 & 0 \\
\hline 2. & 20 & 20 & 0 \\
\hline 3. & 30 & 30 & 0 \\
\hline 4. & 40 & 40 & 0 \\
\hline 5. & 50 & 50 & 0 \\
\hline 6. & 60 & 60 & 1.85 \\
\hline 7. & 70 & 69 & 1.44 \\
\hline 8. & 80 & 78 & 2.56 \\
\hline 9. & 90 & 89 & 1.44 \\
\hline 10. & 100 & 98 & 2.04 \\
\hline 11. & 150 & 147 & 2.04 \\
\hline 12. & 200 & 170 & 17.6 \\
\hline & & &
\end{tabular}

Sensor ultrasonic bekerja dengan memancarkan gelombang ultrasonic dengan frekuensi tertentu dan dengan durasi waktu tertentu yang kemudian sinyal ini merambat sebagai gelombang bunyi dengan kecepatan sekitar $340 \mathrm{~m} / \mathrm{s}$ dipantulkan oleh objek yang berada didepan dan ditangkap oleh reciever Jika dilihat pada tabel pengukuran saat pengukuran jarak $1 \mathrm{~cm}$ dan $2 \mathrm{~cm}$ terjadi kesalahan pengukuran sebesar $66 \%$ dan $50 \%$, hal ini dikarenakan sensor ultrasonic SRF05 hanya mampu membaca jarak terdekat sebesar $3 \mathrm{~cm}$. Untuk pembacaan jarak dari $3 \mathrm{~cm}$ hingga $50 \mathrm{~cm}$ tidak terjadi error atau dapat dikatakan error sebesar 0\%, akan tetapi untuk jarak $60 \mathrm{~cm}$ hingga $550 \mathrm{~cm}$ terjadi error pada pembacaan dengan presentase error dari $0.54 \%$ hingga $17.6 \%$ hal ini dapat disebabkan oleh jarak objek yang jauh dan noise yang mengganggu sinyal ultrasonic yang mana noise merupakan gangguan gelombang dari luar.

Saat pengukuran jarak $600 \mathrm{~cm}$ pembacaan pada sensor $3448 \mathrm{~cm}$ yang mana ini merupakan persentase error terbesar yaitu $82.5 \%$ berdasarkan pengukuran ini dapat dinyatakan sensor ultrasonik tidak mampu membaca jarak lebih dari $600 \mathrm{~cm}$.

Hal ini bersesuain dengan datasheet sensor SRF05 yang hanya mampu membaca jarak dari 3 hingga $500 \mathrm{~cm}$, adapun pengukuran yang terbaca oleh sensor lebih dari $500 \mathrm{~cm}$ merupakan pembacaan jarak yang tidak stabil. 


\subsection{Rangkaian LCD}

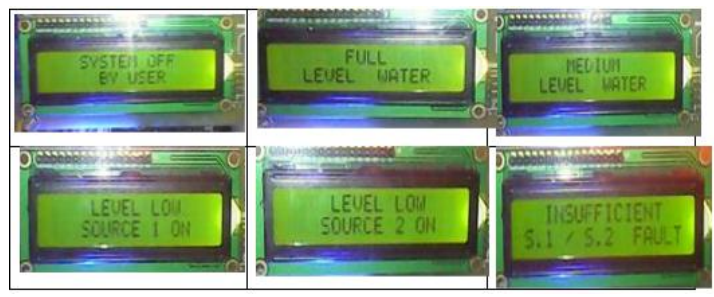

Gambar 3.1. Pengujian LCD

Pada gambar di atas menunjukkan kondisi adanya kegagalan pemenuhan jumlah air pada bak penampungan utama. Tujuannya adalah sebagai tanda bahwa level air pada bak penampungan utama dinyatakan rendah namun kedua sumber suplai dinyatakan tidak mampu memberikan penambahan jumlah air dan kondisi tersebut dianggap sebagai sinyal alarm.

\subsection{Rangkaian Keseluruhan}

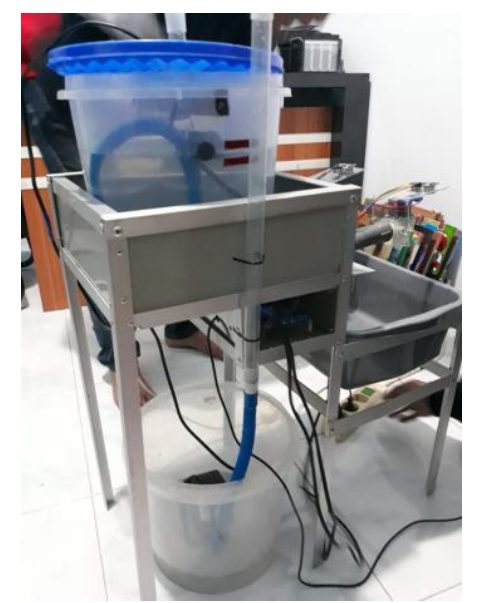

Gambar 3.2. Desain Prototype

Pada rancangan alat ini, pompa akan aktif sampe batas minimum sesuai dengan pergerakan pelampung. Jika posisi pelampung sudah sejajar dengan batas yang ditentukan, maka pompa akan berhenti secara otomatis.

Kemudian untuk sensor ultrasonic pada alat ini diletakan di atas kran untuk mendeteksi pergerakan tangan sehingga air akan keluar otomatis dari bak penampung melalui kran.

\section{Kesimpulan}

Berdasarkan hasil analisis dan pembahasan yang dilakukan pada bab sebelumnya, maka dapat ditarik kesimpulan bahwa alat ini dapat membantu dalam proses pengisian pada bak penampungan karena alat ini bekerja secara otomatis dalam menghidupkan dan mematikan pompa air. Sensor ultrasonik akan terus memonitoring ketinggian permukaan air dengan cara membandingkan volume dan ketinggian air pada bak penampungan air dengan standar/batasan yang telah ditentukan sebelumnya. Apabila volume dan ketinggian air sudah mencapai batasan tertentu, maka pompa air secara otomatis akan mati dan berhenti melakukan pengisian air. Begitu juga sebaliknya, jika volume dan ketinggian air belum mencapai batasan yang telah ditentukan, maka pompa air akan terus hidup dan melakukan pengisian air.

\section{Daftar Pustaka}

[1] Sumardi. 2016. Sistem Kontrol Pengisian Air Otomatis Dengan Dua Sumber Suplai Berbasis Mikrokontroler (ATmega 8535). Dinamika UMT, Volume I No. 2 Hal 84 97

[2] Syamsuddin, Eko.2007. Perancangan Alat Pengatur Suhu Air dan Pengisian Bak Air Secara Otomatis Melalui Short Message Service Berbasis Mikrokontroler. Jurnal TESLA, Vol. 9 No. $1,11-22$

[3] Permana, Adhitya. 2015. Rancang Bangun Sistem Monitoring Volume dan Pengisian Air Menggunakan Sensor Ultrasonic Berbasis Mikrokontroler AVR Atmega 8. Jurnal Coding, Volume 03, No. 2, hal. 7687 ISSN : 2338-493X

[4] Mukhlisin, Imam. 2017. Pendeteksi Volume Tandon Air Secara Otomatis Menggunakan Sensor Ultrasonic Berbasis Arduino Uno R3. Jurnal Qua Teknika, 7(2):55-65

[5] Ilham, Efendi. 2016. Pengertian dan Kelebihan Arduino", avaliable online: http://www.itjurnal.com/

2014/05/pengertian-dan-kelebihan-arduino

[6] Mandarani, dkk. 2016. Perancangan Sistem Deteksi Asap Rokok Menggunakan Layanan Short Message Service (SMS) Alert Berbasis Arduino. ITPress 